\title{
Diagnostic Value of Autoantibodies Against Citrullinated Peptide Antigens in Rheumatoid Arthritis: Comparison of Different Commercial Kits
}

\author{
Romatoid Artritte Sitrulinli Peptit Antikorlarının Tanısal Değeri: \\ Farklı Ticari Kitlerin Karşılaştırılması
}

\author{
Özlem ŞAHİN, ${ }^{1}$ Ece KAPTANOĞLU, ${ }^{2}$ Mustafa Zahir BAKICI, ${ }^{3}$ Hafize SEZER,${ }^{4}$ Hasan ELDEN, ${ }^{1}$ Sami HIZMETLİ \\ Departments of ${ }^{1}$ Physical Medicine and Rehabilitation, ${ }^{2}$ Physical Medicine and Rehabilitation, Division of Rheumatology, \\ ${ }^{3}$ Microbiology and ${ }^{4}$ Biostatistics, Medical Faculty of Cumhuriyet University, Sivas, Turkey
}

\begin{abstract}
Objectives: In this study we tested the diagnostic values of rheumatoid factor (RF), anti-cyclic citrullinated peptide (anti-CCP) and two different commercial anti-mutated citrullinated vimentin (anti-MCV) kits in the differential diagnosis of rheumatoid arthritis (RA) considering that there might also be substantial differences between the performances of the commercial kits.
\end{abstract}

Patients and methods: Thirty-four RA patients, admitted to our rheumatology outpatient clinics between October 2008 and February 2009, and 24 healthy controls were included in this study. Sera of RA patients and healthy controls were analyzed for RF, anti-CCP-2, anti-MCV-548 and anti-MCV-248 autoantibodies with two different commercial kits. Disease activity was determined by disease activity score 28 (DAS-28) in RA patients. Extra-articular involvement was evaluated in RA patients.

Results: In the receiver operating characteristic (ROC) curve analysis perfomed to determine the diagnostic sensitivity, antiCCP-2 had the highest value of area under ROC curve. Sensitivity and specificity was $88 \%$ and $90 \%, 84 \%$ and $100 \%, 80 \%$ and $90 \%$, and $84 \%$ and $100 \%$ for RF, anti-CCP-2, anti-MCV-548, and anti-MCV-248 respectively. DAS-28 had a weak correlation with anti-CCP-2 $(r=0.623)$, anti-MCV-548 $(r=0.481)$, and Anti-MCV-248 $(r=0.408)$. There was no statistically significant difference in $R F$, anti-CCP-2, anti-MCV-548, and anti-MCV-248 values between patients with or without extra-articular involvement or between patients with low or moderate disease activity according to DAS-28 score.

Conclusion: Anti-CCP, RF and anti-MCV autoantibodies are all useful in the differential diagnosis of RA. However, the anti-CCP antibody has a superior diagnostic value compared to the other autoantibodies. The anti-MCV antibodies detected by the antiMCV-248 kit seem more reliable than the anti-MCV antibodies detected by the anti-MCV-548 kit in differential diagnosis of RA due to their high sensitivity and specificity. These findings suggest that different commercial kits may exhibit different performances. Nevertheless, our results need to be confirmed by future studies which should include more patients.

Key words: Anti-CCP-2; Anti-MCV; autoantibodies; rheumatoid factor; rheumatoid arthritis.
Amaç: Bu çalışmada romatoid faktörün (RF), anti-siklik sitrülin peptit (anti-CCP) antikorunun ve anti-mutat sitrülin vimentin (anti-MCV) antikorunun iki farklı ticari kitinin, ticari kitlerin performansları arasında önemli farklılıklar bulunabileceğini de göz önünde bulundurarak, romatoid artritteki (RA) tanısal değerleri test edildi.

Hastalar ve yöntemler: Ekim 2008 ile Şubat 2009 tarihleri arasında romatoloji polikliniğimize başvuran 34 RA'lı hasta ve 24 sağlıklı kontrol çalışmaya alındı. Romatoid artritli hastaların ve sağlıklı gönüllülerin serumlarında iki farklı ticari kitle RF, antiCCP-2, anti-MCV-548 ve anti-MCV-248 otoantikorları çalışıldı. Romatoid artritli hastalarda hastalık aktiviteleri, hastalık aktivite skoru 28 (DAS-28)'e göre belirlendi. Romatoid artritli hastalarda eklem dışı tutulumlar değerlendirildi.

Bulgular: Otoantikorların tanısal duyarlılık ve özgüllüğünü belirlemek için yapılan alıcı işletim karakteristiği (ROC) eğrisi analizinde en yüksek eğri altında kalan alan değeri anti-CCP-2'ye aitti. Duyarlılık ve özgüllük RF için $\% 88$ ve $\% 90$, anti-CCP-2 için $\% 84$ ve $\% 100$, anti-MCV-548 için $\% 80$ ve $\% 90$ ve anti-MCV-248 için \%84 ve $\% 100$ idi. DAS-28 ile anti-CCP-2 $(r=0.623)$, anti-MCV-548 ( $r=0.481)$ ve anti-MCV-248 ( $r=0.408)$ arasında zayıf bir korelasyon vardı. Ekstraartiküler tutulumu olan ve olmayan hastaların ve DAS-28'e göre düşük veya orta şiddette hastalık aktivitesi olan hastaların RF, anti-CCP-2, anti-MCV-548 ve anti-MCV-248 değerleri arasında istatistiksel olarak anlamlı bir fark yoktu.

Sonuç: Anti-CCP, RF ve anti-MCV otoantikorları RA'nın ayırıcı tanısında faydalıdır. Fakat, anti-CCP antikoru diğer otoantikorlarla karşılaştırıldığında daha üstün bir tanısal değere sahiptir. Anti-MCV antikorunun tespitinde kullanılan anti-MCV-248 kitinin duyarlılık ve özgüllüğü anti-MCV-548 kitine göre daha yüksek olarak bulundu. Bu bulgular farklı ticari kitlerin farklı performans sergileyebileceğini akla getirmektedir. Bununla birlikte sonuçlarımızın daha fazla hastanın dahil edildiği çalışmalarla desteklenmesi gerekmektedir.

Anahtar sözcükler: Anti-CCP-2; Anti-MCV; otoantikorlar; romatoid faktör; romatoid artrit.

Received: March 18, 2010 Accepted: October 16, 2010

Correspondence: Özlem Şahin, M.D. Cumhuriyet Üniversitesi Tıp Fakültesi Fiziksel Tıp ve Rehabilitasyon Anabilim Dalı, 58140 Sivas, Turkey.

Tel: +90 346 - 2580682 e-mail: sahinftr@yahoo.com

(02011 Turkish League Against Rheumatism. All rights reserved. 
Rheumatoid arthritis (RA) is a disabling disease in which early diagnosis is crucial. Autoantibodies are of special interest in diagnosing the disease. Although rheumatoid factor (RF) is the gold standard, ${ }^{[1]}$ more specific and sensitive autoantibodies have been under research in recent years. ${ }^{[2]}$ There are also different commercial kits of these autoantibodies.

Antibodies against citrullinated peptides have recently gained special importance in the diagnosis of RA. ${ }^{[3,4]}$ The citrullination of arginine to citrulline possibly results in protein unfolding and consequent aberrant recognition by the immune system. These antibodies are thought to be triggered by the genes that increase susceptibility to RA as well as by many environmental agents. ${ }^{[3]}$ The anti-cyclic citrullinated peptide (anti-CCP) has a comparable sensitivity to RF (50-75\%) with a higher specificity $(90-95 \%)^{[3,5]}$ and is the new candidate for the crown of RF. Along with anti-CCP, there has been interest in another new marker, anti-mutated citrullinated vimentin (anti-MCV). There are many studies which have investigated the value of the anti-MCV antibodies in connective tissue diseases. ${ }^{[6-8]} \mathrm{A}$ meta-analysis reported the sensitivity and specificity of antiMCV antibody as between 0.64-0.84, and 0.79-0.96 respectively, which are almost equal to those of antiCCP in RA. ${ }^{[8]}$ However, studies comparing different commercial kits are missing in the literature, particularly for anti-MCV antibodies.

In this study, we investigated the diagnostic value of $\mathrm{RF}$, anti-CCP and two different anti-MCV commercial kits in the differential diagnosis of RA.

\section{PATIENTS AND METHODS}

Thirty-four RA patients classified according to the American College of Rheumatology 1987 revised criteria $^{[1]}$ were consecutively recruited from the outpatient rheumatology clinics between October 2008 and February 2009. Twenty-four healthy volunteers were included in the study as the control group. Disease activity score 28 (DAS-28) was evaluated and scores $\leq 3.2$ were considered as low disease activity. ${ }^{[9]}$ Disease duration and extra-articular involvement were also documented.

Sera of $34 \mathrm{RA}$ patients and 24 healthy controls were analyzed for the presence of RF, anti-CCP-2, and anti-MCV with both Orgentec-548 and Orgentec-248 kits. Anti-MCV antibodies were tested in $25 \mathrm{RA}$ and 22 controls by the Orgentec-248 kit due to limitation in availability of the kit. Serum samples were stored at
$-80{ }^{\circ} \mathrm{C}$ until analysis. Blinded laboratory technicians obtained all results.

Commercially available enzyme linked immunosorbent assays (ELISA) detected anti-MCV and anti-CCP-2 antibodies. Results were expressed as $\mathrm{U} / \mathrm{ml}$. Anti-MCV was evaluated with Orgentec-548 kit (Anti-MCV-548) Germany, (instrument: Triturus, Italy) and with Orgentec-248 (Anti-MCV-248) kit Germany, (instrument: Alegria, Germany). AntiCCP-2 was performed with Aeskulisa kit, Germany (instrument: Triturus, Italy).

The rheumatoid factor was studied with Beckman Coulter, USA kit (instrument: Beckman Coulter immage, USA), by nephelometry.

The erythrocyte sedimentation rate (ESR) and $\mathrm{C}$-reactive protein $(\mathrm{CRP})$ were studied in patients with RA and healthy controls.

The local ethics committee approved the study protocol. Informed consent was obtained from each subject and the study was performed in accordance with the principles of the Declaration of Helsinki.

\section{Statistical analysis}

Receiver operating characteristic (ROC) curve analysis was obtained for determining the diagnostic values of assays. Optimal cut off values were obtained by the maximum value of sensitivity plus " 1 -specificity". Mann-Whitney $U$ and chi-square tests were used to compare the data between RA and healthy controls with and without extra-articular involvement in RA patients and the groups with low and moderate disease activity scores. Spearman's correlation coefficient was calculated to assess the relationship between parameters. Statistical significance was assumed at $\mathrm{p}<0.05$.

\section{RESULTS}

Demographic, clinical and serological parameters of the patients and the controls are given in table 1 . The age and sex of the patients and the control group were comparable. Positivity ratios of all autoantibodies were significantly higher in RA patients compared to controls ( $p<0.001$ for all). The median (minimummaximum) values of the antibody assays are given in table 2. Median values of all autoantibodies were significantly higher in RA patients compared to controls $(\mathrm{p}<0.001$ for all).

In healthy controls, anti-CCP-2 and anti-MCV-248 were not positive in any subject while RF and antiMCV-548 were positive in $13.6 \%$ and $17.4 \%$ respectively. 
Table 1. Demographic, clinical and serological parameters of the groups

\begin{tabular}{|c|c|c|c|c|c|c|c|c|c|}
\hline & \multicolumn{4}{|c|}{ Rheumatoid arthritis $(\mathrm{n}=34)$} & \multicolumn{4}{|c|}{ Healthy controls $(\mathrm{n}=24)$} & \multirow[t]{2}{*}{$p$} \\
\hline & $\mathrm{n}$ & $\%$ & Median & (min.-max.) & $\mathrm{n}$ & $\%$ & Median & (min.-max.) & \\
\hline Age (years) ${ }^{*}$ & & & 50 & $(23-76)$ & & & 45 & $(28-61)$ & $\mathrm{p}>0.05$ \\
\hline \multicolumn{10}{|l|}{ Sex } \\
\hline Male $^{\star *}$ & 11 & & & & 5 & & & & $\mathrm{p}>0.05$ \\
\hline Female $^{* *}$ & 23 & & & & 19 & & & & $\mathrm{p}>0.05$ \\
\hline Erythrocyte sedimentation rate $(\mathrm{mm} / \mathrm{h})^{*}$ & & & 20.5 & $(5-105)$ & & & 11 & $(1-42)$ & $\mathrm{p}<0.01$ \\
\hline C-reactive protein $(\mathrm{mg} / \mathrm{dL})^{*}$ & & & 10.9 & $(1-62.1)$ & & & 2.2 & $(1-7.4)$ & $\mathrm{p}<0.001$ \\
\hline Disease activity score- $28^{\star}$ & & & 3.7 & $(1.9-5.5)$ & - & & - & & \\
\hline Disease duration (years) ${ }^{*}$ & & & 4 & $(1-20)$ & - & & - & & \\
\hline Rheumatoid factor $(\mathrm{IU} / \mathrm{mL})$ positivity ${ }^{\star *}$ & 28 & 82.4 & & & 3 & 13.6 & & & $\mathrm{p}<0.001$ \\
\hline Anti-CCP-2 (U/mL) positivity ${ }^{* *}$ & 27 & 79.4 & & & 0 & 0 & & & $\mathrm{p}<0.001$ \\
\hline Anti-MCV-548 (U/mL) positivity ${ }^{* *}$ & 24 & 70.6 & & & 4 & 17.4 & & & $\mathrm{p}<0.001$ \\
\hline Anti-MCV-248 (U/mL) positivity ${ }^{\star *}$ & 21 & $84^{* * *}$ & & & 0 & $0^{* * *}$ & & & $\mathrm{p}<0.001$ \\
\hline
\end{tabular}

Anti-MCV-248 was positive in only one out of four anti-CCP-2 negative RA patients while anti-MCV-548 was negative in all four. In one RF negative patient, anti-CCP-2, anti-MCV-548 and anti-MCV-248 were all positive. In one patient anti-MCV-248 was positive where all others were negative.

To determine the diagnostic value of RF, anti-CCP-2, anti-MCV-548, and anti-MCV-248, we performed ROC curve analysis for discriminating RA from controls (Table3, Figure 1). The area under curve (AUC), sensitivity and specificity of the RF, anti-CCP-2, anti-MCV-548 and anti-MCV-248 are given in table 3. Figure 1 demonstrates the comparison of the ROC curves. The difference in AUC between anti-CCP-2 and anti-MCV-548 ( $\mathrm{p}=0.019)$ was significant. There was no difference in AUC among other parameters. The optimum cut-off values were determined as seen in table 3 .

In the RA group there were seven patients (20.5\%) with extra-articular involvement. There was no statistically significant difference between the RA patients with and without extra-articular involvement regarding RF $(\mathrm{p}=0.565)$, anti-CCP-2 $(\mathrm{p}=0.359)$, antiMCV-548 ( $\mathrm{p}=0.966)$ and anti-MCV-248 antibody $(\mathrm{p}=0.918)$ levels. In six $(85.7 \%)$ out of these seven RA patients, RF, anti-CCP-2, and anti-MCV-548 were positive. Anti-MCV-248 could be performed in five out of these seven patients, and all of them (100\%) were positive.

According to the DAS-28 score, the RA patients were classified as low and moderate disease activity with the cut-off value of 3.2. There was no significant difference between these groups regarding RF $(p=0.955)$, antiCCP-2 $(\mathrm{p}=0.100)$, anti-MCV-548 $(\mathrm{p}=0.112)$ and antiMCV-248 ( $\mathrm{p}=0.608)$ levels.

Anti-MCV-548 was found to be correlated with anti-CCP-2 ( $\mathrm{r}=0.785, \mathrm{p}<0.001), \mathrm{RF}(\mathrm{r}=0.481, \mathrm{p}<0.01)$ and DAS-28 $(\mathrm{r}=0.455, \mathrm{p}<0.01)$. Anti-MCV-248 was found to be correlated with anti-CCP-2 $(\mathrm{r}=0.768$, $\mathrm{p}<0.001), \mathrm{RF}(\mathrm{r}=0.408, \mathrm{p}<0.05)$ and DAS $-28(\mathrm{r}=0.429$, $\mathrm{p}<0.05)$. DAS-28 was also correlated with anti-CCP-2 antibodies $(\mathrm{r}=0.413, \mathrm{p}<0.05)$. Anti-CCP-2 and RF were correlated $(\mathrm{r}=0.623, \mathrm{p}<0.001$; Table 4$)$.

Table 2. Quantitative results of the assays of the groups

\begin{tabular}{|c|c|c|c|c|c|}
\hline \multirow[t]{2}{*}{ Assay } & \multicolumn{2}{|c|}{ Rheumatoid arthritis $(n=34)$} & \multicolumn{2}{|c|}{ Healthy controls $(\mathrm{n}=24)$} & \multirow[t]{2}{*}{$p$} \\
\hline & Median & (min.-max.) & Median & (min.-max.) & \\
\hline Rheumatoid factor (IU/mL) & 40.1 & $(11-1220)$ & 16 & $(6-21.8)$ & $\mathrm{p}<0.001$ \\
\hline Anti-CCP-2 (U/mL) & 93.5 & $(2.28-301)$ & 0.2 & $(0-7)$ & $\mathrm{p}<0.001$ \\
\hline Anti-MCV-548 (U/mL) & 121.5 & $(0.8-1001)$ & 10 & $(0.6-50.3)$ & $\mathrm{p}<0.001$ \\
\hline Anti-MCV-248 (U/mL)* & 128.5 & $(7.9-1001)^{\star}$ & 9.3 & $(5.8-18.4)^{\star}$ & $\mathrm{p}<0.001$ \\
\hline
\end{tabular}


Table 3. Diagnostic value of the assays at manufacturers' and optimal levels for rheumatoid arthritis $(\mathrm{n}=34)$ and healthy controls $(n=24)$

\begin{tabular}{|c|c|c|c|c|c|c|c|c|}
\hline \multirow[t]{2}{*}{ Assay } & \multirow{2}{*}{$\begin{array}{l}\text { AUC 95\% CI } \\
\text { (lower bound-upper bound) }\end{array}$} & \multicolumn{3}{|c|}{ Manufacturers' cut-off } & \multicolumn{4}{|c|}{ Optimal cut-off } \\
\hline & & Cutoff & Sn (\%) & Sp (\%) & Cutoff & Sn $(\%)$ & Sp (\%) & $\mathrm{Sn}+\mathrm{Sp}$ \\
\hline $\mathrm{RF}(\mathrm{IU} / \mathrm{mL})$ & $\begin{array}{l}0.949 \\
(0.888-1.000)\end{array}$ & 20 & 88 & 90 & 20.8 & 84 & 95 & 178 \\
\hline Anti-CCP-2 (U/mL) & $\begin{array}{l}0.994^{\star *} \\
(0.980-1.000)\end{array}$ & 12 & 84 & 100 & 7.8 & 96 & 100 & 196 \\
\hline Anti-MCV-548 (U/mL) & $\begin{array}{l}0.880^{* *} \\
(0.775-0.985)\end{array}$ & 20 & 80 & 90 & 28.4 & 80 & 95 & 175 \\
\hline Anti-MCV-248 (U/mL)* & $\begin{array}{l}0.915 \\
(0.826-1.000)\end{array}$ & 20 & 84 & 100 & 20 & 84 & 100 & 184 \\
\hline
\end{tabular}

Erythrocyte sedimentation rate and CRP values were significantly higher in RA patients compared to controls ( $\mathrm{p}<0.01$ for ESR, and $\mathrm{p}<0.001$ for CRP).

\section{DISCUSSION}

In the present study, we investigated the diagnostic performances of RF, anti-CCP-2 and anti-MCV antibodies by two different commercial kits in distinguishing RA from healthy controls.

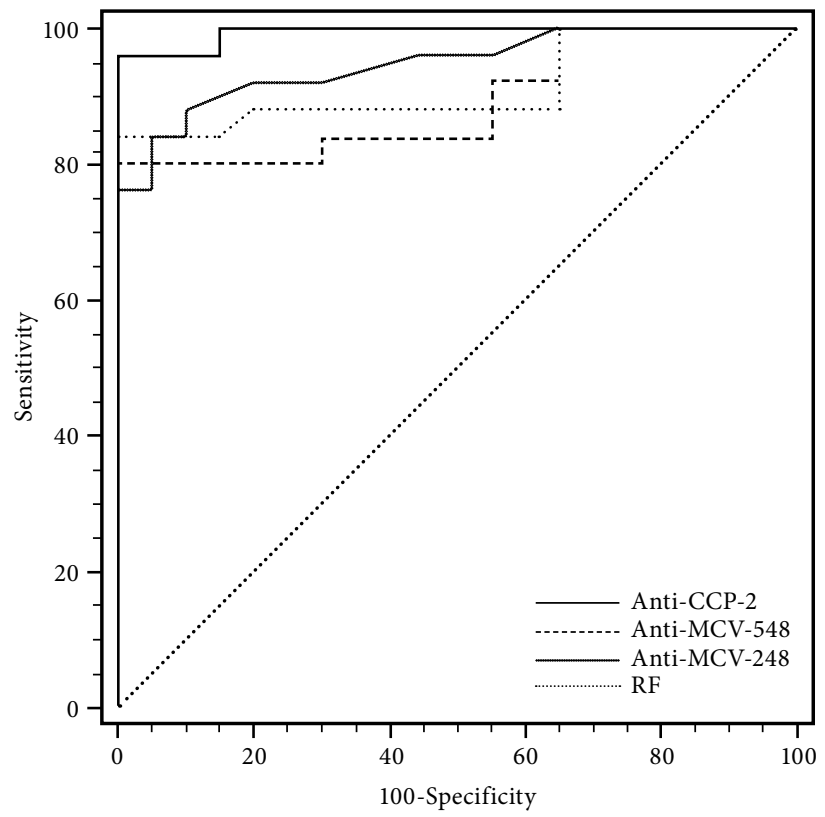

Figure 1. Analysis of diagnostic values of anti-CCP-2, antiMCV-548, anti-MCV-248, and RF in patients with rheumatoid arthritis.

Anti-CCP-2: Anti-cyclic citrullinated peptide antibody 2; Anti-MCV-548: Anti-mutated citrullinated vimentin antibody-studied by Orgentec-548 kit; Anti-MCV-248: Anti-mutated citrullinated vimentin antibody-studied by Orgentec-248 kit; RF: Rheumatoid factor.
Anti-MCV is suggested to be positive in antiCCP negative RA patients. ${ }^{[7,10]}$ Wagner et al. ${ }^{[7]}$ found anti-MCV positivity to be $13.6 \%(n=8)$ in anti-CCP negative patients (59 patients). In a study by Nicaise-Roland et al., ${ }^{[10]}$ anti-MCV was found to be positive in $18.4 \%(\mathrm{n}=14)$ of anti-CCP negative patients $(\mathrm{n}=76)$. In the present study, anti-MCV-248 was positive in only one $(25 \%)$ of the four antiCCP-2 negative RA patients while anti-MCV-548 was negative in all four. This patient with antiMCV-248 positive was male, had moderate disease activity (DAS $=4.7)$ and had a disease duration of 15 years. Rheumatoid factor was also negative besides anti-CCP-2 and anti-MCV-548 in this patient. As we observed this result in only one patient, we could neither compare our study with other studies nor make any conclusion.

With regard to the ROC curve analysis, the results of this study showed that anti-CCP-2 and anti-MCV-248 have equal sensitivity and specificity in RA patients. There was significant difference between anti-CCP-2 and anti-MCV-548 in favor of anti-CCP-2 ( $\mathrm{p}=0.019)$. The AUC was the highest in anti-CCP-2. The sensitivity and specificity of anti-CCP-2 and anti-MCV-248 were $84 \%$ and $100 \%$ whereas the sensitivity and specificity of RF and anti-MCV-548 were $88 \%$ and $90 \%$ and $80 \%$ and $90 \%$, respectively. Although the curves of both anti-MCV tests overlap, the anti-MCV-248 assay appears to be a more sensitive and specific test. The sensitivity and specificity of the autoantibodies for RA vary in the literature between $55-84 \%$ and $77-98 \%$ for anti-CCP, and $49-74 \%$ and $79-96 \%$ for anti-MCV..$^{[6,7,10-17]}$ Our results are comparable with the literature. 


\begin{tabular}{|c|c|c|c|c|c|c|}
\hline & $\mathrm{RF}(\mathrm{IU} / \mathrm{mL})$ & Anti-CCP-2 & Anti-MCV-548 & Anti-MCV-248* & DAS-28 & ESR \\
\hline \multirow[t]{2}{*}{ Anti-CCP-2 (U/mL) } & $\mathrm{r}=0.623$ & & & & & \\
\hline & $\mathrm{p}<0.001$ & & & & & \\
\hline \multirow[t]{2}{*}{ Anti-MCV-548 (U/mL) } & $\mathrm{r}=0.481$ & $\mathrm{r}=0.785$ & & & & \\
\hline & $\mathrm{p}<0.01$ & $\mathrm{p}<0.001$ & & & & \\
\hline \multirow[t]{2}{*}{ Anti-MCV-248 $(\mathrm{U} / \mathrm{mL})^{\star}$} & $\mathrm{r}=0.408$ & $\mathrm{r}=0.768$ & $\mathrm{r}=0.940$ & & & \\
\hline & $\mathrm{p}<0.05$ & $\mathrm{p}<0.001$ & $\mathrm{p}<0.001$ & & & \\
\hline \multirow[t]{2}{*}{ Disease activity score- 28} & $\mathrm{r}=0.153$ & $\mathrm{r}=0.413$ & $\mathrm{r}=0.455$ & $\mathrm{r}=0.429$ & & \\
\hline & $\mathrm{p}=0.38$ & $\mathrm{p}<0.05$ & $\mathrm{p}<0.01$ & $\mathrm{p}<0.05$ & & \\
\hline \multirow[t]{2}{*}{$\operatorname{ESR}(\mathrm{mm} / \mathrm{h})$} & $\mathrm{r}=0.249$ & $\mathrm{r}=0.467$ & $\mathrm{r}=0.447$ & $\mathrm{r}=0.625$ & $\mathrm{r}=0.603$ & \\
\hline & $\mathrm{p}=0.15$ & $\mathrm{p}<0.01$ & $\mathrm{p}<0.01$ & $\mathrm{p}<0.01$ & $\mathrm{p}<0.001$ & \\
\hline \multirow[t]{2}{*}{$\mathrm{CRP}(\mathrm{mg} / \mathrm{dL})$} & $\mathrm{r}=0.385$ & $\mathrm{r}=0.311$ & $\mathrm{r}=0.181$ & $\mathrm{r}=0.218$ & $\mathrm{r}=0.297$ & $\mathrm{r}=0.444$ \\
\hline & $\mathrm{p}<0.05$ & $\mathrm{p}=0.07$ & $\mathrm{p}=0.34$ & $\mathrm{p}=0.29$ & $\mathrm{p}=0.08$ & $\mathrm{p}<0.01$ \\
\hline
\end{tabular}

RF: Rheumatoid factor; Anti-CCP-2: Anti-cyclic citrullinated peptide antibody 2; Anti-MCV-548: Anti-mutated citrullinated vimentin antibody-studied by Orgentec-548 kit; Anti-MCV-248: Anti-mutated citrullinated vimentin antibody-studied by Orgentec-248 kit; ESR: Erythrocyte sedimentation rate; CRP: C-reactive protein; ${ }^{*}$ : Anti-MCV-248 test was performed in 25 rheumatoid arthritis patients.

Although there are studies favoring anti-MCV over anti-CCP, ${ }^{[14,17]}$ the majority of studies found anti-CCP to be more specific than anti-MCV for RA. ${ }^{[6,7,10,11,14,16]}$ The results of the present study also support this outcome for the anti-MCV-548 kit. However, regarding the anti-MCV-248 kit, there was no statistically significant difference in sensitivity and specificity between antiCCP-2 and anti-MCV antibodies.

To our knowledge, this is the first study comparing the different anti-MCV kits. Though not statistically confirmed, our results suggest that the sensitivity and specificity of the anti-MCV-248 ELISA with Alegria instrument is superior to anti-MCV-548.

Sghiri et al. ${ }^{[1]]}$ reported that there was no relationship between extra-articular involvement and anti-MCV, anti-CCP, and RF. Bas et al. ${ }^{[18]}$ confirmed these results in their study in which they found that anti-filaggrin antibodies directed against a citrullinated protein were not associated with extra-articular involvement. We have likewise failed to note a relationship between extra-articular involvement and any of these antibodies.

In the present study, DAS-28 was weakly correlated with anti-CCP-2, anti-MCV-548 and anti-MCV-248 antibodies. There was no significant difference between patients with low and moderate disease activity in terms of RF, anti-CCP-2, anti-MCV-548 and antiMCV-248 antibodies. There are studies suggesting a significant correlation between antibodies and disease activity ${ }^{[7,10,12,15,19]}$ while others did not find any correlation. ${ }^{[13,17]}$ In our study, anti-MCV-548 and antiMCV-248 were strongly correlated with anti-CCP-2 but weakly correlated with RF. This finding is also consistent with the literature. ${ }^{[6,12]}$
In conclusion, anti-MCV antibodies do not appear to have an advantage over anti-CCP for diagnosing RA. However, there are differences between the performances of different anti-MCV kits. In the present study, antiMCV antibodies detected by the anti-MCV-248 kit seem more sensitive and specific for RA. Although the result of this study needs to be confirmed in future studies which should include more patients, it deserves attention as it points out the differences in commercial kits which should be taken into consideration in daily clinical practice.

\section{Declaration of conflicting interests}

The authors declared no conflicts of interest with respect to the authorship and/or publication of this article.

\section{Funding}

The authors received no financial support for the research and/or authorship of this article.

\section{REFERENCES}

1. Arnett FC, Edworthy SM, Bloch DA, McShane DJ, Fries JF, Cooper NS, et al. The American Rheumatism Association 1987 revised criteria for the classification of rheumatoid arthritis. Arthritis Rheum 1988;31:315-24.

2. Rodríguez-Mahou M, López-Longo FJ, Sánchez-Ramón S, Estecha A, García-Segovia A, Rodríguez-Molina JJ, et al. Association of anti-cyclic citrullinated peptide and anti$\mathrm{Sa} /$ citrullinated vimentin autoantibodies in rheumatoid arthritis. Arthritis Rheum 2006;55:657-61.

3. Klareskog L, Rönnelid J, Lundberg K, Padyukov L, Alfredsson L. Immunity to citrullinated proteins in rheumatoid arthritis. Annu Rev Immunol 2008;26:651-75.

4. Engelmann R, Brandt J, Eggert M, Karberg K, Krause A, Neeck G, et al. IgG1 and IgG4 are the predominant subclasses among auto-antibodies against two citrullinated antigens in RA. Rheumatology (Oxford) 2008;47:1489-92. 
5. Sauerland U, Becker H, Seidel M, Schotte H, Willeke $\mathrm{P}$, Schorat A, et al. Clinical utility of the anti-CCP assay: experiences with 700 patients. Ann N Y Acad Sci 2005;1050:314-8.

6. Mutlu N, Bicakcigil M, Tasan DA, Kaya A, Yavuz S, Ozden AI. Comparative performance analysis of 4 different anticitrullinated protein assays in the diagnosis of rheumatoid arthritis. J Rheumatol 2009;36:491-500.

7. Wagner E, Skoumal M, Bayer PM, Klaushofer K. Antibody against mutated citrullinated vimentin: a new sensitive marker in the diagnosis of rheumatoid arthritis. Rheumatol Int 2009;29:1315-21.

8. Luime JJ, Colin EM, Hazes JM, Lubberts E. Does antimutated citrullinated vimentin have additional value as a serological marker in the diagnostic and prognostic investigation of patients with rheumatoid arthritis? A systematic review. Ann Rheum Dis 2010;69:337-44.

9. Saag KG, Teng GG, Patkar NM, Anuntiyo J, Finney C, Curtis JR, et al. American College of Rheumatology 2008 recommendations for the use of nonbiologic and biologic disease-modifying antirheumatic drugs in rheumatoid arthritis. Arthritis Rheum 2008;59:762-84.

10. Nicaise Roland P, Grootenboer Mignot S, Bruns A, Hurtado M, Palazzo E, Hayem G, et al. Antibodies to mutated citrullinated vimentin for diagnosing rheumatoid arthritis in anti-CCP-negative patients and for monitoring infliximab therapy. Arthritis Res Ther 2008;10:R142.

11. Sghiri R, Bouajina E, Bargaoui D, Harzallah L, Fredj HB, Sammoud S, et al. Value of anti-mutated citrullinated vimentin antibodies in diagnosing rheumatoid arthritis. Rheumatol Int 2008;29:59-62.

12. Mathsson L, Mullazehi M, Wick MC, Sjöberg O, van Vollenhoven R, Klareskog L, et al. Antibodies against citrullinated vimentin in rheumatoid arthritis: higher sensitivity and extended prognostic value concerning future radiographic progression as compared with antibodies against cyclic citrullinated peptides. Arthritis Rheum 2008;58:36-45.

13. Ursum J, Nielen MM, van Schaardenburg D, van der Horst AR, van de Stadt RJ, Dijkmans BA, et al. Antibodies to mutated citrullinated vimentin and disease activity score in early arthritis: a cohort study. Arthritis Res Ther 2008;10:R12.

14. Dejaco C, Klotz W, Larcher H, Duftner C, Schirmer M, Herold M. Diagnostic value of antibodies against a modified citrullinated vimentin in rheumatoid arthritis. Arthritis Res Ther 2006;8:R119.

15. Bang H, Egerer K, Gauliard A, Lüthke K, Rudolph PE, Fredenhagen G, et al. Mutation and citrullination modifies vimentin to a novel autoantigen for rheumatoid arthritis. Arthritis Rheum 2007;56:2503-11.

16. Innala L, Kokkonen H, Eriksson C, Jidell E, Berglin E, Dahlqvst SR. Antibodies against mutated citrullinated vimentin are a better predictor of disease activity at 24 months in early rheumatoid arthritis than antibodies against cyclic citrullinated peptides. J Rheumatol 2008;35:1002-8.

17. Poulsom H, Charles PJ. Antibodies to citrullinated vimentin are a specific and sensitive marker for the diagnosis of rheumatoid arthritis. Clin Rev Allergy Immunol 2008;34:4-10.

18. Bas S, Perneger TV, Mikhnevitch E, Seitz M, Tiercy JM, Roux-Lombard P, et al. Association of rheumatoid factors and anti-filaggrin antibodies with severity of erosions in rheumatoid arthritis. Rheumatology (Oxford) 2000;39:1082-8.

19. Keskin G, Inal A, Keskin D, Pekel A, Baysal O, Dizer U, et al. Diagnostic utility of anti-cyclic citrullinated peptide and anti-modified citrullinated vimentin antibodies in rheumatoid arthritis. Protein Pept Lett 2008;15:314-7. 